\title{
Production and Characterization of Crude Protease from RS1 Isolate from silage of Floating Bladderwort (Utricularia gibba)
}

\author{
Ace Baehaki ${ }^{1}$, Arif Hidayat ${ }^{1}$, Rodiana Nopianti ${ }^{1}$, and Nuni Gofar ${ }^{2}$ \\ ${ }^{1}$ Study Program of Fisheries Product Technology, Faculty of Agriculture, Univesitas Sriwijaya, Indralaya, \\ South Sumatera, Indonesia \\ ${ }^{2}$ Study Program of Soil Sciences, Faculty of Agriculture, Univesitas Sriwijaya, Indralaya, South Sumatera, \\ Indonesia
}

\begin{abstract}
The purpose of this research was to produce and characterizing crude protease from RS1 isolate of swamp plant silage. The optimum production time of RS1 isolate was $45 \mathrm{~h}$. The optimum pH and temperature of protease from RS1 isolate were 10 and $45^{\circ} \mathrm{C}$, respectively. Ion $\mathrm{Mg}^{3+}$ increased RS1 protease whereas ion of $\mathrm{Na}^{+}$, $\mathrm{K}^{+}, \mathrm{Fe}^{2+}$, and $\mathrm{Zn}^{2+}$ inhibited protease from RS1 isolate. Study on the effect of metals ion indicated that protease from RS1 isolate was metaloenzyme. Based analysis on SDS-PAGE, the molecular weight of RS1 protease had 12 bands with molecular weights ranging from $34.75 \mathrm{kDa}$ to $263.53 \mathrm{kDa}$.
\end{abstract}

Keywords: Protease; RS1 Isolate ; Production; Characterization.

\section{Introduction}

Enzymes are proteins produced by living organisms which catalyze the chemical reaction in hugely efficient ways and are environment friendly. They have substantial advantages over chemical catalysts, in its specificity, high catalytic activity, its capability to work at moderate temperatures, and the ability to be produced in large amounts ${ }^{1}$. Enzymes are diverse polymer molecules produced by living cells. Enzymes are biological catalysts (also known as biocatalysts) that speed up biochemical reactions in living organisms. They can also be extracted from cells and then used to catalyse a wide range of commercially important processes ${ }^{2}$.

Protease enzymes are enzymes needed by all living things to hydrolyze peptide bonds in proteins to oligopeptides and amino acids. Proteolytic enzymes are capable of hydrolyzing peptide bonds in proteins ${ }^{3}$. Sources of protease enzymes are known to come from animals, microbes, and plants.

Microorganisms are the most widely used source of enzymes compared to plants and animals. As a source of enzymes, microorganisms are more beneficial because of their rapid growth, the results of which can be improved more easily through the regulation of growth conditions and genetic engineering. One source of enzyme-producing microbes is from silage of floating bladderwort (Utricularia gibba) with the addition of 5\% fine bran. Screening of bacteria from the silage of swamp plants was done to select and obtain bacteria that produce protease enzymes.

*Corresponding author: A. Baehaki

Email address: abaehaki.unsri@gmail.com

DOI: http://dx.doi.org/10.13171/mjc02003251256ab
Based on the results of preliminary research shows screening of protease-producing bacteria from silage of floating bladderwort (Utricularia gibba) was obtained RS1 isolate which had the highest proteolytic index which would then be used in the production and characterization of the resulting protease enzyme. Enzyme characterization includes the effect of $\mathrm{pH}$, temperature and metal ions on enzyme activity, this protease characterization aims to determine the optimal conditions $(\mathrm{pH}$, temperature and influence of metal ions) in enzyme application.

\section{Material and Methods}

\subsection{Materials}

The materials used in this study were Floating bladderwort (Utricularia gibba), RS1 isolate, trichloroacetic acid (Merck), $\mathrm{NaOH}$ (Merck), tryptone (Merck), yeast extract (Merck), $\mathrm{NaCl}$ (Merck). The tools used include $\mathrm{pH}$ meter, OHAUS analytical balance, incubator, micropipette (Single Channel Capp 10-100 Ul, USA), autoclave (Hirayama, Japan), hotplate (Cimarec, United Kingdom) and a spectrophotometer.

\subsection{Protease Production}

The RS1 bacterial strain was inoculated for 1-2 loops on the Luria Bertani Broth (LB) media. The cell growth was monitored turbidimetrically through absorbance at $\lambda=620 \mathrm{~nm}$. As much as $10 \%$ of seedling culture with an optical density of 0.8 (at $620 \mathrm{~nm}$ ) was sub-cultured into the same media for enzyme production.

Received January 8, 2020

Accepted March 3, 2020

Published March 25 11, 2020 


\subsection{Assay of Protease Activity}

Protease activity was measured by the Bergmeyer ${ }^{4}$ method using a $2 \%(\mathrm{w} / \mathrm{v})$ with casein Hammerstein as substrate. One unit of protease activity was defined as the amount of enzyme that can produce one $\mu \mathrm{mol}$ of tyrosine products per min under measurement conditions.

\subsection{Protein Assay}

Protein determination was carried out using the method of Bradford ${ }^{5} .5 \mathrm{ml}$ of Bradford reagent was added to $0.1 \mathrm{ml}$ sample in the test tube. The blank was made by mixing $0.1 \mathrm{ml}$ of distilled water and reacted with $5 \mathrm{ml}$ of Bradford reagent. After about $5 \mathrm{~min}$, each reaction mixture was measured for absorbance at $\lambda=$ $595 \mathrm{~nm}$. Bovine serum albumin was used as the protein standard.

\subsection{Effects of pH on Enzyme Activity}

The effect of $\mathrm{pH}$ on protease activity was carried out by reacting enzymes and substrates at $\mathrm{pH} 5-11$ at $37^{\circ} \mathrm{C}$ for 60 min with universal buffer. Enzyme activity was analyzed quantitatively by the Bergmeyer method ${ }^{4}$.

\subsection{Effect of Temperature on Enzyme Activity}

The protease enzyme used in the characterization was crude extract protease. The effect of temperature on enzyme activity was carried out by reacting $50 \mu \mathrm{l}$ protease with $250 \mu \mathrm{l}$ casein solution and $250 \mu 10.05$ $\mathrm{mM}$ phosphate buffer with optimum $\mathrm{pH}$ and incubated at $35,40,45,50,55,60$, and $65^{\circ} \mathrm{C}$ for
60 min. Enzyme activity was analyzed quantitatively by Bergmeyer method ${ }^{4}$.

\subsection{Effects of Metal Ions}

The metal ions used are $\mathrm{NaCl}, \mathrm{KCl}, \mathrm{FeCl}_{2}, \mathrm{ZnCl}_{2}$ and $\mathrm{MgCl}_{2}$. The test of the influence of metal ions is carried out when measuring enzyme activity. The reaction starts with the addition of a substrate, then the metal ions and buffer are added. The activity of the enzyme is compared with the activity of non-metal ion enzymes (100\%). Enzyme activity was analyzed by Bergmeyer method ${ }^{4}$.

\subsection{Determination of Molecular Weight with SDS- PAGE}

The determination of molecular weight is done by electrophoresis under denaturating polyacrylamideSDS (SDS-PAGE) with $8 \%$ polyacrylamide gels using the Laemmli method ${ }^{6}$. The gel consists of two types, namely $8 \%$ separating gel and $4 \%$ holding gel.

\section{Results and Discussion}

\subsection{Protease Production}

Protease production was carried out on the Luria Bertani (LB) broth medium after being cultured in the same medium until it reaches $\mathrm{OD}=0.8$. Incubation was conducted at $37^{\circ} \mathrm{C}$ and samples were taken for analysis of enzyme activity, protein concentration and cell growth. The optimum production of protease from RS1 isolate can be seen in Figure 1.

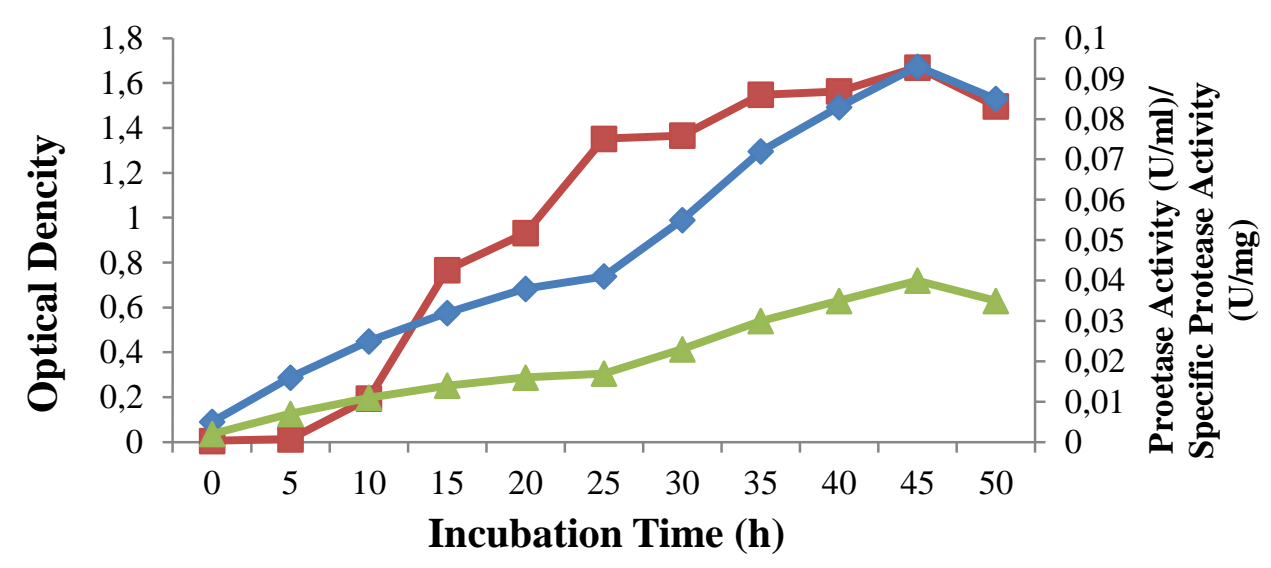

Figure 1. Protease production of RS1 isolate from silage of floating bladderwort $(-\square$-optical density, protease activity, $-\Lambda$ - specific activity)

Incubation period affects the enzyme production significantly and it varies from $24 \mathrm{~h}$ to a week depending upon type of microorganism and other culture conditions such as source of media, inoculum size, metabolic state of cell $\mathrm{pH}$ and temperature ${ }^{7}$. Protease from RS1 isolate has optimum protease production at the $45 \mathrm{~h}$ with protease activity was 0.091 $\mathrm{U} / \mathrm{ml}$. Assay of specific activities was also carried out. To determine the specific activity of proteases, the enzyme protein concentration was measured. Protein concentrations were analyzed concurrently when measuring protease activity. The optimum specific protease activity from RS1 isolate was $0.042 \mathrm{U} / \mathrm{mg}$. Bacillus subtilis ATCC 633 and Bacillus sp. UFLA $817 \mathrm{CF}$ have been reported to show maximum protease activity after $24 \mathrm{~h}$ growth ${ }^{8}$. Protease production by Bacillus pumilus UN-31-C-42 started $16 \mathrm{~h}$ after incubation ${ }^{9}$. Optimum incubation time for protease production by $B$. licheniformis and Bacillus coagulans has been reported as $96 \mathrm{~h}^{10}$. 


\subsection{Effect of pH on Enzyme Activity}

All enzymatic reactions were influenced by $\mathrm{pH}$, so a buffer was needed to control the $\mathrm{pH}$ of the reaction. In general, enzymes are ampholytic, which means that the enzyme has a dissociation constant in the acid group and its base group, especially in the carboxylterminal residue group and its amine terminal group.
It was estimated that changes in the activity of enzymes were caused by changes in ionization in the ionic enzyme groups, i.e. on the active side or another side which indirectly affects the active side. Figure 2 shows the effect of $\mathrm{pH}$ on the crude protease activity from RS1 isolate.

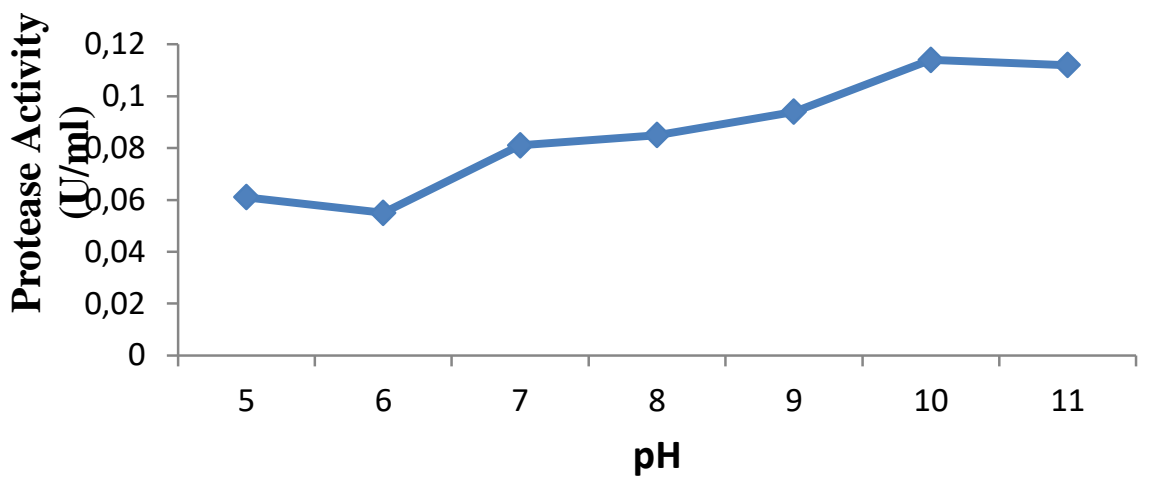

Figure 2. Effect of $\mathrm{pH}$ on Protease Activity from RS1 Isolate

The optimum protease activity from RS1 isolate was $\mathrm{pH} 10$. The optimum $\mathrm{pH}$ value of protease from RS1 isolate was the same as the optimum $\mathrm{pH}$ of the protease of Bacillus licheniformis KBDL48 ${ }^{11}$. The optimum $\mathrm{pH}$ protease from RS1 isolate was greater than the protease from Bacillus aryabhattai K36 which has optimum activity at $\mathrm{pH} 8{ }^{12}$ and Bacillus licehniformis $\mathrm{F} 11.4$ protease which has optimum $\mathrm{pH}$ at $\mathrm{pH} 9^{13}$.

\subsection{Effect of Temperature on Enzyme Activity}

In general, each enzyme has a maximum activity at a specific temperature. Enzyme activity will increase with increasing temperature until the optimum temperature was reached. A further rise in temperature will cause the enzyme activity to decrease. From the results of the assay of enzyme activity at various temperatures can be seen in Figure 3.

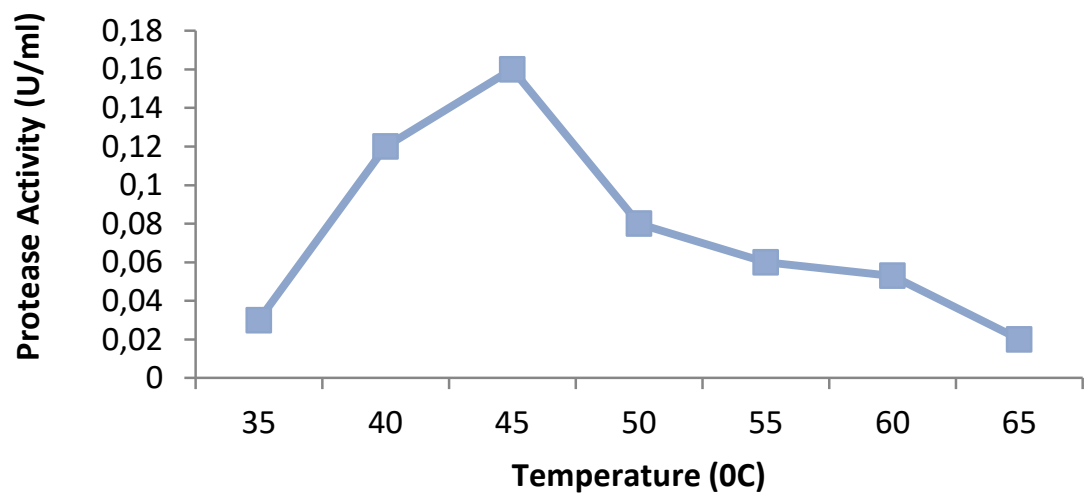

Figure 3. Effect of temperature on Protease Activity from RS1 isolate

The optimum temperature of the protease from RS1 isolate was $45^{\circ} \mathrm{C}$. The optimum temperature in this study was the same as the protease from Myceliophthora thermophila ${ }^{14}$ and was greater than the optimum temperature for the protease from Bacillus cereus FT 1 that was $35^{\circ} \mathrm{C}{ }^{15}$, but more compared to Bacillus licheniformis $\mathrm{F} 11.4$ protease which has an optimum temperature of $50^{\circ} \mathrm{C}{ }^{13}$, Bacillus licheniformis UV-910 protease which has an optimum temperature of $60^{\circ} \mathrm{C}{ }^{16}$ and the Bacillus HUTTBS62 protease with temperature the optimum was $80^{\circ} \mathrm{C}^{17}$.

\subsection{Effects of Metal Ions on Protease Activity}

Some enzymes need metal ions as a cofactor to support enzyme catalytic efficiency. The effect of metal ions on protease activity from RS1 isolate was shown in Table 1. 
Table 1. Effects of Metal Ions on Protease Activity from RS1 Isolate.

\begin{tabular}{|c|c|c|}
\hline Treatment & Concentration $(\mathbf{m M})$ & Activity $(\mathbf{U} / \mathbf{m l})$ \\
\hline Control & - & 0.074 \\
\hline $\mathbf{N a C l}$ & 5 & 0.034 \\
\hline $\mathbf{K C l}$ & 5 & 0.043 \\
\hline $\mathbf{F e C l}$ & 5 & 0.000 \\
\hline $\mathbf{Z n C l}_{2}$ & 5 & 0.016 \\
\hline $\mathbf{M g C l}_{3}$ & 5 & 0.101 \\
\hline
\end{tabular}

Table 1 shows the $\mathrm{Mg}^{3+}$ ion as an activator of the protease from RS1 isolate because it can increase protease activity compared to controls. Metal ions that can increase enzyme activity are cofactors of these enzymes. $\mathrm{Mn}^{2+}$ activated enzyme activity of protease from Pseudomonas thermaerum GW1 by fivefold ${ }^{18}$. Ions of $\mathrm{Na}^{+}, \mathrm{K}^{+}, \mathrm{Fe}^{2+}$ and $\mathrm{Zn}^{2+}$ can reduce activity compared to control so that this ions as protease inhibitors of protease from RS1 isolate. Metal ions which can reduce the activity of enzymes may not be cofactors for these enzymes. The effect of metal ions on protease activity indicates that protease from RS1 isolate was a metalloenzim.

\subsection{Determination of Protease Molecular Weight} The results of SDS-PAGE protease from RS1 isolate can be seen in Figure 4. SDS-PAGE analysis of crude extract protease shows that protease from RS1 isolate has 12 bands with molecular weights ranging from $34.75 \mathrm{kDa}$ to $263.53 \mathrm{kDa}$.

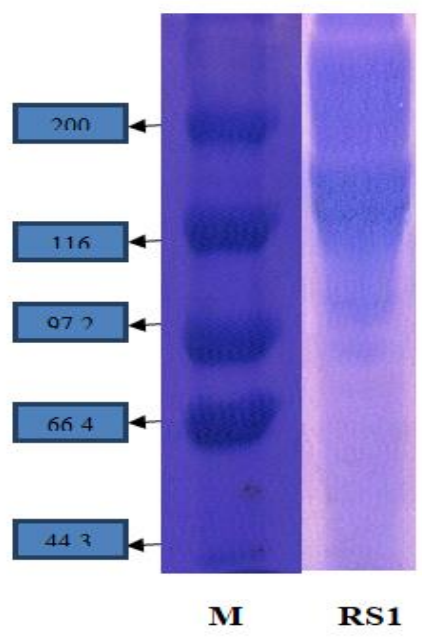

Figure 4. SDS-PAGE analysis of crude extracts of protease enzymes from RS1 isolate

Different molecular weight enzyme proteases will be obtained from different types of bacteria. Some protease from other bacteria were Bacillus sp. HS08A has a molecular weight of $30.9 \mathrm{kDa}{ }^{19}$ and Bacillus sp. S17110 with a molecular weight of $75 \mathrm{kDa}^{20}$.

\section{Conclusions}

The protease from RS1 isolate has the highest activity $(0.091 \mathrm{U} / \mathrm{ml})$ after incubating for $45 \mathrm{~h}$ in LB media. The characterization of protease activity from RS1 isolate was $\mathrm{pH}$ optimum at $\mathrm{pH} 10$ and temperature at $45^{\circ} \mathrm{C} . \mathrm{Mg}^{2+}$ ion as an activator while ions of $\mathrm{Na}^{+}, \mathrm{K}^{+}$, $\mathrm{Fe}^{2+}$ and $\mathrm{Zn}^{2+}$ as inhibitors. The effect of metal ions on protease activity indicates that protease from RS1 isolate was a metalloenzyme. SDS-PAGE analysis on crude extract protease showed that protease from RS1 isolate had 12 bands with molecular weights ranging from $34.75 \mathrm{kDa}$ to $263.53 \mathrm{kDa}$.

\section{References}

1- C. Sandhya, K. Madhavan Nampoothiri, A. Pandey, In Microbial Enzyme and Biotransformation: Microbial protease; ed. by J. L. Barredo; Humana Press Inc: USA, 2005,

2- P. K. Robinson. Enzymes: principles and biotechnological applications. Essays in Biochem, 2015, 59, 1-41.

3- J. A. Mótyán, F. Tóth, J. Tőzsér, Research applications of proteolytic enzymes in molecular biology, Biomolecules, 2013, 3, 4, 923-942. https://doi.org/10.3390/biom3040923

4- H.U. Bergmeyer, Methods of Enzymatic Analysis Vol 2. Academic Press: New York, 1974.

5- M. M. Bradford, A rapid and sensitive methodfor quantitation of microgram quantities of protein utilizing the principle of protein dyebinding, Anal Biochem., 1976, 72, 234-254. https://doi.org/10.1016/0003-2697(76)90527-3 
6- U.K. Laemmli, Cleavage of structural protein during the assembly of the heat of bacteriophage T4, Nature, 1970, 227, 680-685. https://www.nature.com/articles/227680a0

7- K. M. Sharma, R. Kumar, S. Panwar, A. Kumar, Microbial alkaline protease: optimization of production parameters and their properties, J Genetic Eng Biotechnol, 2017, 15, 1, 115-126. http://dx.doi.org/10.1016/j.jgeb.2017.02.001

8- D. R. Dias, D.M. Vilela, M.P.C. Silvestre, R.F. Schwan, Alkaline protease from Bacillus sp. isolated from coffee bean grown on cheese whey, World J Microbiol Biotechnol, 2008, 24, 2027 2034. https://doi.org/10.1007/s1 1274-008-9706-6

9- Q. Huang, Y. Peng, X. Li, H. Wang, Y. Zhang, Purification and characterization of an extracellular alkaline serine protease with dehairing function from Bacillus pumilus, Curr Microbiol, 2003, 46, 169-173. https://doi.org/10.1007/s00284-002-3850-2

10- S. Asokan, C. Jayanthi, Alkaline protease production by Bacillus licheniformis and Bacillus coagulans, J Cell Tissue Res, 2010, 10, 2119-2123. Doi: 10.7324/JAPS.2018.8219

11- A. P. Pathak, K.B. Desmukh, Akaline protease production, extraction \& characterization from alkaliphilic Bacillus licheniformis KBDL4: a lonar soda lake isolate, Indian J Exp Biol, 2012, 50, 569-5

12- K.M. Sharma, R. Kumar, S. Vats, A. Gupta, 2014. Production, partial purification and characterization of alkaline protease from Bacillus aryabhattai K3. Int J Adv Pharm, Biol. Chem., 2014, 3, 2, 290-298.

13- A. Baehaki, Sukarno, D. Syah, S. Setyahadi, M.T. Suhartono. Production and characterization of collagenolytic protease from Bacillus licheniformis F11.4 originated from Indonesia, Asian J Chem, 2014, 26, 10, 2861-2864. https://doi.org/10.14233/ajchem.2014.15863.

14- Y. N. A. H. Neto, L. C.G. de Oliveira, A. H. C. de Oliveira, J. C. Rosa, M. A. Juliano, L. Juliano, A. Rodrigues, H. Cabral. Determination of specificity and biochemical characteristics of neutral protease isolated from Myceliophthora thermophila. Prot Peptide Lett., 2015, 22, 11, 972-982

15- B. Asha, M. Palaniswamy, Optimization of alkaline protease production by Bacillus cereus FT 1 isolated from soil, J Appl Pharm Sci, 2018, 8,2, 119-127. Doi: 10.7324/JAPS.2018.8219

16- M. Nadeem, J.I. Qazi, Q. Syed, M. Gulsher, Purification and characterization of an alkaline protease from Bacillus licheniformis UV-9 for detergent formulations. Songklanakarin J Sci Technol, 2013, 35, 2, 187-195.

17- H. Aqel, F. Al-Quadan, T.K. Yousef, A novel neutral protease from thermophilic Bacillus strain HUTBS62, J Biosci Biotech, 2012, 1, 2, 117-123.

18- S. Gaur, S. Agrahari, N. Wadhwa, Purification of protease from Pseudomonas thermaerum GW1 isolated from poultry waste site, Open Microbiol J, 2010, 4, 67-74. https://dx.doi.org/10.2174\%2F187428580100401 0067

19- G. R. Huang, T.J. Ying, P. Huo, J.X. Jiang, Purification and characterization of a protease from Thermophilic Bacillus strain HS08, Afr J Biotechnol, 2006, 5, 2433-2438.

20- S. C. Jung, H. Paik, M. S. Kim, K.S. Baik, W. Lee, C.N. Seong, S.K. Choi, InhA-like protease secreted by Bacillus sp. S17110 inhabited in turban shell, J Microbiol, 2007, 45, 402-408. 